\title{
UJI EFEKTIVITAS MEDIA TANAM UNTUK PEMBENIHAN PADI PANDANWANGI (Oryza sativa $L$ )
}

\author{
Oleh: \\ Ramli*) \\ Ujang Muhamad**)
}

\begin{abstract}
Abstrak
Beras Pandanwangi Cianjur telah terdaftar Indikasi Geografis (IG), tanggal 16 Oktober 2015, yang tumbuh di Indonesia dan khusus nya hanya tumbuh di Kabupaten Cianjur dan hanya 7 kecamatan saja yaitu Kecamatan Warungkondang, Gekbrong, Cilaku, Cibeber, Cianjur, dan Cugenang. Media tanam pun sangat penting untuk pertumbuhan padi Pandawangi karena media tanam adalah fase awal atau fase vegetatif untuk pertumbuhan padi, adapun media tanam yang sering digunakan oleh petani yaitu berupa Pupuk Kandang Sapi, Pupuk Kandang Kambing, Pupuk Kandang ayam, Sabut kelapa Kotoran Cacing dan masih banyak lagi yang bisa digunakan sebagai media tanam. Penelitian ini dilaksanakan selama bulan Juni 2019, bertempat di Green House Fakultas Sains Terapan Universitas Suryakancana Cianjur. Penelitian ini menggunakan 5 perlakuan media tanam dengan masingmasing 100 benih Pandawangi dengan parameter penelitian yaitu perkecambahan, tinggi tanaman padi, dan panjang akar padi pandanwangi. Hasil penelitian menunjukkan bahwa Pupuk Kandang Ayam sangat berpenagruh terhadap pertumbuhan padi pandanwangi karena pupuk kandang ayam mengandung unsure hara antara lain N,P dan $\mathrm{K}$ dan mineral logam seperti magnesium,kalium dan kalsium yang sangat dibutuhkan oleh tanaman Padi Pandawangi pada Fase Vegetatif.
\end{abstract}

Kata kunci : Pupuk Kandang, Pupuk Organik dan Padi Pandanwangi (Oryza sativa L).

\begin{abstract}
Pandanwangi Cianjur Rice (MP3C) In 2015 Pandanwangi Cianjur Rice was registered with Geographical Indications (IG) on 16 October 2015, which grew in Indonesia and specifically only grew in Cianjur district and only 7 sub-districts, Warungkondang, Gekprong, Cilaku, Cibeber, Cianjur, and Cugenang. The growing media is also very important for the growth of rice paddy field because the planting media is the initial phase or the vegetative phase for rice growth, while the planting media are often used by farmers, such as Cow Manure Fertilizer, Goat Manure, Cbicken Manure Fertilizer, Coconut Fiber Worm Manure and still many more can be used as planting media. The research was carried out for 15 days during June 2019, located at the Green House of the Faculty of Applied Sciences, Suryakancana University Cianjur. This study uses 5 treatments of 100 planting media with 100 Pandawangi Seeds as comparison media, with research parameters namely germination, height of rice plants, and length of pandanwangi rice roots. The results of this study indicate that the effect of chicken manure is very influential on the growth of pandanwangi rice because chicken manure contains nutrient elements such as N, P and K and metal minerals such as magnesium, potassium and calcium which are needed by Pandawangi Paddy plants in the Vegetative Phase.
\end{abstract}

Keywords: Manure, Organic Fertilizer and Pandanwangi Rice (Oryza sativa var aromatic).

*) Dosen Fakultas Sains Terapan UNSUR

**) Alumni Fakultas Sains Terapan UNSUR 


\section{PENDAHULUAN}

Pandanwangi merupakan padi lokal Cianjur yang memiliki aroma khas dan kepulenannya serta sudah sangat populer. Karakteristik padi Pandanwangi yang membedakannya dengan tanaman padi lainnya yitu berumur panjang 155 hari dengan tingginya mencapai $150 \mathrm{~cm}$ serta nilai jual yang lebih tinggi dibandingkan dengan beras Cianjur lainnya (Dinas Pertanian Kabupaten Cianjur, 2009; MP3C, 2015)

Pupuk kandang dapat memberikan dampak secara alami dan tidak merusak tanah, mikro seperti besi, seng, boron,kobalt dan molibdenium, dan menyediakan unsur makro seperti nitrogen, fosfor, kalium, kalsium, dan belerang. Selain itu, dengan adanya ketersediaan pupuk kandang ini berfungsi untuk meningkatkan daya tahan terhadap air, aktivitas mikrobiologi tanah (biologi), nilai kapasitas tukar kation dan memperbaiki struktur tanah (fisika) baik secara langsung ataupun tidak langsung.

Bahwa setiap media mempunyai pengaruh terhadap pertumbuhan tanaman, sehingga perlu adanya penelitian tentang perbandingan setiap media yang diunggulkan, khusunya pada tanaman Padi Pandanwangi.

\section{METODE PENELITIAN}

Waktu pelakasanaan penelitian ini dilakukan selama selama bulan Juni 2019, bertempat di Green House Fakultas Sains Terapan Universitas Suryakancana Cianjur.

Penelitian ini dilakukan secara eksperimental dengan pola non faktorial Rancangan Acak Lengkap (RAL) .Rancangan penelitian menggunakan 5 perlakuan dengan 100 benih Pandanwangi sebagai sampel.

C1 :Media tanam berupa tanah 500 gram + 500 gram media tanam berupa kotoran hewan ayam yang sudah di fermentasikan sebelumnya.

C2 :Media tanam berupa tanah 500 gram +500 gram media tanam berupa kotoran hewan kambing yang sudah di fermentasikan sebelumnya.

C3 :Media tanam berupa tanah 500 gram + 500 gram media tanam berupa kotoran hewan sapi yang sudah di fermentasikan sebelumnya.

C4 :Media tanam berupa tanah 500 gram + 500 gram media tanam berupa kotoran cacing atau cascing.

C5: Media tanam berupa tanah 500 gram + 500 gram media tanam berupa cocopeat (bekas sabut kelapa).

Perlakuan ini mulai dari pagi hingga sore hari dengan perlakuan yang sama berupa pemberian pupuk yang sama, penyiraman yang sama, cahaya yang sama dan akan dihitung daya tumbuh benih nya.

Teknik pengumpulan data yang telah dilakukan 15 HST dengan mengamati 3 parameter diantaranya adalah sebagai berikut:

1. Pengamatan viabilitas benih (kemampuan daya hidup benih) dengan cara pengukuran tanaman yang tumbuh sehat dan tanaman yang kerdil.

jumlah benih berkecamabh $\frac{\text { jumlah benih yang di kecambahkan }}{x} 100 \%$

2. Pengamatan tinggi tanaman $(\mathrm{cm})$ yaitu dengan menggunakan meteran sebagai alat ukur, Pada pengukuran ini dilakukan mulai dari bagian panggal batang sampai ujung daun tanaman tertinggi.

3. Pengamatan panjang akar $(\mathrm{cm})$ yaitu diukur dengan meteran dan pengukuran dilakukan pada saat akhir penelitian.

Data yang diperoleh dari hasil pengamatan setelah perlakuan sampai masa vegetatif kemudian diolah dan dianalisis, kemudian untuk faktor perlakuan yang berpengaruh dilakukan dengan uji lanjut atau Duncan Multiple Range Test (DMRT) pada taraf 5\% menggunakan bantuan software yaitu Ms. Excel dan SPSS. 


\section{HASIL DAN PEMBAHASAN}

\section{Pengamatan viabilitas benih padi pandawangi}

Parameter yang pertama yang diamati yaitu viabilitas benih (kemampuan benih untuk berkecambah) dan dengan pengukuran tanaman yang lengkap. Perkecambahan merupakan proses metabolisme biji hingga dapat menghasilkan pertumbuhan dari komponen kecambah (Plumula dan Radikula). Dari semua perlakuan menunjukkan hasil yang sama, hal ini di sebabkan perkecambahan benih menunjukan $100 \%$ dikarena sebelum dilakukakannya penelitian, benih diuji atau diseleksi dulu terlebih dahulu dengan menggunakan sistem SRI, sehingga $\mathrm{HO}$ diterima dan H1 di tolak. Selain itu penyabab nya diduga karena dipengaruhi oleh proses Imbibisi (masuk nya air ke dalam biji). Menurut Lakitan (1996), jadi perlakuan lama perendaman pada biji akan memengaruhi permeabilitas membran sel dan perbedaan potensial air antara di dalam dan di luar sel.

\section{Pengamatan tinggi tanaman benih Padi Pandanwangi}

Pengukuran tinggi bibit menggunakan meteran sebagai alat ukur, yaitu mulai dari pangkal batang hingga ujung daun teratas. Selama 12 hari satuan pengukuran dalam centimeter $(\mathrm{cm})$ diamati setiap 3 hari sekali.

Berdasarkan hasil analisis sidak ragam (ANOVA) dan di uji lanjut oleh DMRT dengan $\propto 5 \%$ ditunjukkan oleh tabel 1 .

Tabel 1.Hasil uji DMRT Pengaruh Tinggi Tanaman Padi Pandanwangi yang Dilakukan Selama 15 Hari

\begin{tabular}{lccccc}
\hline \multirow{2}{*}{\multicolumn{1}{c}{ Perlakuan }} & \multicolumn{5}{c}{$\begin{array}{c}\text { Tinggi tanaman Padi Pandanwangi (cm) } \\
\text { Waktu Pengamatan (hari) }\end{array}$} \\
\cline { 2 - 6 } & $\mathbf{3}$ (hari) & $\mathbf{6}$ (hari) & $\mathbf{9}$ (hari) & $\mathbf{1 2}$ (hari) & $\mathbf{1 5}$ (hari) \\
\hline A (Pupuk Sapi) & $2.3 \mathrm{c}$ & $3.3 \mathrm{c}$ & $5.8 \mathrm{c}$ & $7.6 \mathrm{c}$ & $10.1 \mathrm{bc}$ \\
B (Pupuk Kambing) & $2.4 \mathrm{~b}$ & $3.3 \mathrm{c}$ & $7.8 \mathrm{a}$ & $9.4 \mathrm{~b}$ & $11.0 \mathrm{~b}$ \\
C (Pupuk Ayam) & $2.8 \mathrm{a}$ & $5.6 \mathrm{a}$ & $7.3 \mathrm{~b}$ & $10.8 \mathrm{a}$ & $13.4 \mathrm{a}$ \\
D (Cocopeat) & $2.4 \mathrm{~b}$ & $4.1 \mathrm{~b}$ & $5.7 \mathrm{c}$ & $7.4 \mathrm{c}$ & $9.0 \mathrm{c}$ \\
E (Cascing) & $2.4 \mathrm{bc}$ & $4.0 \mathrm{~b}$ & $5.8 \mathrm{c}$ & $7.5 \mathrm{c}$ & $9.8 \mathrm{bc}$ \\
\hline
\end{tabular}

Keterangan: Angka yang diikuti burufyang sama menunjukan tidak ada beda nyata berdasarkan uji DMRT.

Berdasarkan hasil penelitian pada pengamatan pertama menunjukkan perlakuan C (pupuk kandang ayam) berdasarkan tabel 1. merupakan nilai ratarata tinggi tanaman yang paling besar dibandingkan kelima perlakuan lainnya. Perlakuan A (pupuk kandang sapi) dan B (pupuk kandang kambing) menunjukan hasil yang berbedanyata dengan perlakuan lainnya. Sedangkan perlakuan D (Cocopeat) dan E (Cascing) menunjukkan hasil yang tidak berbeda nyata.

Pengamatan kedua pada tabel 1. menunjukan perlakuan $C$ (pupuk kandang ayam) berbeda nyata dengan perlakuan lainnya dengan nilai 5 sedangkan D (Cocopeat) dan E (Cascing) memiliki perbedaan yang tidak berbeda nyata dengan yang perlakuan yang lainnya lalu perlakuan A (pupuk kandang sapi) dan B (pupuk kandang kambing) tidak berbeda nyata dengan yang lain nya.
Pengamatan ke tiga pada tabel 1. menunjukan perlakuan B (pupuk kandang kambing) berbeda nyata dengan perlakuan lainnya dengan nilai 7,8 sedangkan C (pupuk kandang ayam) memiliki perbedaan yang berbeda nyata dengan yang perlakuan yang lainnya lalu perlakuan A (pupuk kandang sapi) $\mathrm{D}$ (Cocopeat) dan E (Cascing) tidak berbeda nyata dengan yang lain nya karena memiliki nilai yang hampir sama.

Pengamatan ke empat pada tabel 1. menunjukan perlakuan $\mathrm{C}$ (pupuk kandang ayam) berbeda nyata dengan perlakuan lainnya dengan nilai 10.8 sedangkan B (pupuk kandang kambing) berberda nyata dengan perlakuan lainnya. Sehingga perlakuan E (Cascing) D (Cocopeat) dan A (pupuk kandang sapi) memiliki perbedaan yang tidak berbeda nyata dengan yang perlakuan yang lainnya. 
Pengamatan ke lima pada tabel 1. menunjukan perlakuan $C$ (pupuk kandang ayam) berbeda nyata dengan perlakuan lainnya dengan nilai 13,4 sedangkan B (pupuk kandang kambing) dan D (Cocopeat) memiliki perbedan yang berdeda nyata dengan yang lain nya, lalu A (pupuk kandang sapi) dan E ( Cascing) tidak berdeda nyata dengan perlakuan manapun. Menurut Widowati (2005) pupuk kandang kotoran ayam secara umum mempunyai kelebihan dalam kecepatan penyediaan hara, komposisi hara seperti kadar N, P, K, dan Ca dibanding pupuk kandang sapi dan kambing. Pupuk kandang kotoran ayam relatif lebih cepat terdekomposisi serta mempunyai kadar hara yang cukup pula jika dibandingkan dengan jumlah unit yang sama dengan pupuk kandang lainnya.

Sedangkan perlakuan A (pupuk kandang sapi) dan perlakuan B (pupuk kandang kambing) mempunyai nilai yang tidak berdeda jauh perlakuan pupuk $\mathrm{C}$ (pupuk kandang ayam) karena perlakuan A dan $\mathrm{B}$ kandungan hampir sama tetapi memiliki kekurang masing-masing. Menurut Hartatik,et al (2005) menyebutkan bahwa pupuk kandang sapi memiliki kadar air yang sangat tinggi dan memiliki C/N rasio $>40$, dan Petani umumnya menyebutnya sebagai pupuk dingin. Bila pukan dengan kadar air yang tinggi diaplikasikan secara langsung akan memerlukan tenaga yang lebih banyak serta proses pelepasan amoniak masih berlangsung. Kandang kambing umum nya memiliki tekstur yang khas karena berbentuk butiran-butiran yang agak sukar dipecah secara fisik sehingga sangat berpengaruh terhadap proses dekomposisi dan proses penyediaan haranya. Nilai rasio $\mathrm{C} / \mathrm{N}$ pukan kambing umumnya masih di atas 30 (Hartatik, et al 2005).

Selanjutnya perlakuan D (pupuk cocopeat) atau sabut kelapa memliki nilai rata-rata pertumbuhan yaitu berkisaran 9,0c serta perbedaan yang sangat jauh dengan perlakuan -perlakuan A, B, C, E ini di sebabkan karena cocopeat atau sabut kelapa memiliki banyak mengandung tanin. Zat tanin diketahui sebagai zat yang menghambat pertumbuhan tanaman. Untuk menghilangkan zat tanin yang berlebihan maka bisa dilakukan dengan cara merendam cocopeat di dalam air bersih selama beberapa jam, lalu diaduk sampai air berbusa putih.

\section{Pengamatan Panjang Akar Benih Padi Pandawangi}

Akar adalah salah satu bagian terpenting dari tumbuhan yang tumbuh bawah dalam media tanam. Akar juga tumbuh pada fase vegetatif utama yang memasok air, mineral dan bahan-bahan yang penting untuk pertumbuhan dan perkembangan tanaman. Pengamatan panjang akar (cm) yaitu diukur dengan meteran dan pengukuran dilakukan pada saat akhir penelitian.

Berdasarkan hasil analisi sidak ragam (ANOVA) dan diuji lanjut oleh DMRT dengan $\propto 5 \%$ ditunjukan oleh gambar 1 . 


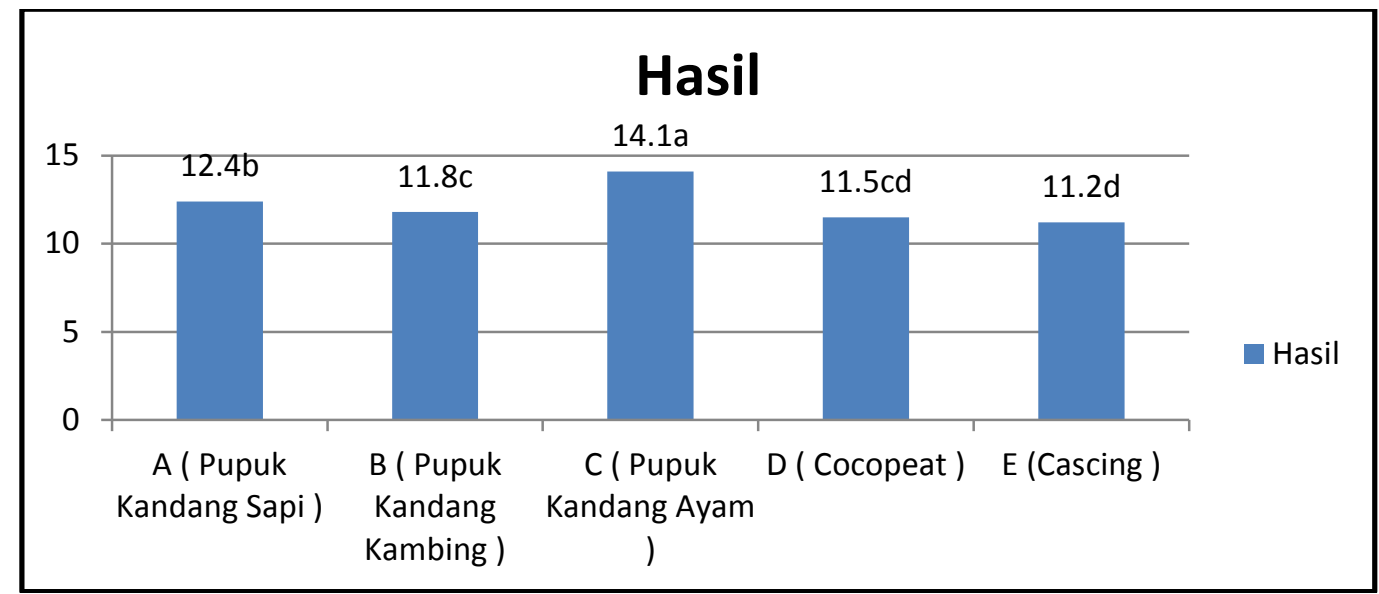

Gambar 1. Hasil uji DMRT Pengaruh Panjang akar Padi Pandanwangi yang Dilakukan Selama 15 Hari

Berdasarkan hasil penelitian 1. bahwa perlakuan C (pupuk kandang ayam) sangat berbeda nyata terhadap perlakuan lainya dalam pertumbuhan panjang akar. Hal ini dilihat bahwa perlakuan C meiliki nilai 14,1 a yang menyatakan nilai tertinggi dibandingkan dengan perlakukan lainya. Sedangkan perlakuan A (pupuk kandang sapi) sangat berbeda nyata dengan perlakuan yang lain nya, lalu perlakuan B (pupuk kandang kambing) berbeda nyata dengan perlakuan yang lain. Sedangkan D (Cocopeat) tidak berbeda nyata dengan lainnya tetapi perlakuan E (Cascing) berbeda nyata dengan semua nya. Bahwa perlakuan $\mathrm{C}$ yaitu kandungan pupuk kandang ayam memiliki nilai $\mathrm{N}$ (nitrogen) yang sangat tinggi dibandingkan dengan pupuk organik lainnya, hal ini didukung oleh Donahue et al. (1977) bahwa pupuk kandang memiliki kandungan Nitrogen dan fosfor (1-2\%) yang sangat tininggi berkisar antara 5-8\%. Sedangkan menurut gambar 4.2 pada perlakuan E menunjukan bahwa nilai dari $\mathrm{E}$ itu adalah 11,2 a menunjukan bahwa perlakuan $\mathrm{E}$ terhadap panjang akar tidak berpengaruh karena $\mathrm{E}$ mempunyai nilai $\mathrm{N}(1,40)$ dan fosfor $(4,33)$ menurut Agung, A.K. 2007 yang tinggi sehingga tidak berperngaruh pada panjang akar padi pandawangi.

\section{KESIMPULAN}

Berdasarkan hasil penelitian dapat dilihat bahwa hasil perlakuan pertumbuhan pembenihan media tanam dapat berpengaruh terhadap perkecambahan dengan nilai $100 \%$. Selain itu nilai untuk masing masing media tanam yaitu, pupuk kandang ayam tinggi tanaman 13.4 a, panjang akar 14.1 a, pupuk kandang kambing tinggi tanaman 11.0 b, panjang akar $11.8 \mathrm{c}$,pupuk kandang sapi tinggi tanaman $10.1 \mathrm{bc}$, panjang akar $12.4 \mathrm{~b}$, pupuk cacing tinggi tanaman $10.1 \mathrm{bc}$, panjang akar $11.2 \mathrm{~d}$ dan sabut kelapa tinggi tanaman $9.0 \mathrm{c}$, panjang akar $11.5 \mathrm{~cd}$.

Jadi dapat kita simpulkan bahwa pengaruh perlakuan media tanam tanah yang dicampur dengan pupuk kandang ayam berpengaruh terhadap tinggi tanaman 13.4 a dan panjang akar $14.1 \mathrm{a}$ padi Pandawangi.

\section{DAFTAR PUSTAKA}

Agung, A.K. 2007. Pengaruh Pemberian Pupuk Kascing Terbadap Pertumbuban Tanaman Kangkung Darat (Ipomea Reptans Poir). Universitas Muhamadiyah Metro.

Donahue, R.L., R.W. Miller, J.C. Shickluna. 1977. An Introduction to Soils and Plant Growth, 4th ed. Prentice-Hall, Inc. New Jersey.

Hartatik, W., D. Setyorini, L.R. Widowati, dan S. Widati. 2005. Laporan Akbir 
Penelitian Teknologi Pengelolaan Hara pada Budidaya Pertanian Organik. Laporan Bagian Proyek Penelitian Sumberdaya Tanah dan Proyek Pengkajian Teknologi Pertanian Partisipatif (Tidak dipublikasikan).

Lakitan, B. 1996. Fisiologi Pertumbuhan dan Perkembangan Tanaman. Jakarta:Raja Grafindo Persada.

Masyarakat Pelestari Padi Pandanwangi Cianjur (MP3C). 2015. Buku Persyaratan Permohonan Pendaftaran Indikasi Geografis Beras Pandanwangi Cianjur. Cianjur (ID).

Widowati, L.R., Sri Widati, U. Jaenudin, dan W. Hartatik.2005. Pengaruh Kompos Pupuk Organik yang Diperkaya dengan Bahan Mineral dan Pupuk Hayati terhadap Sifat-sifat Tanah, Serapan Hara dan Produksi Sayuran Organik. Laporan Proyek Penelitian Program Pengembangan Agribisnis, Balai Penelitian Tanah, TA 2005. 